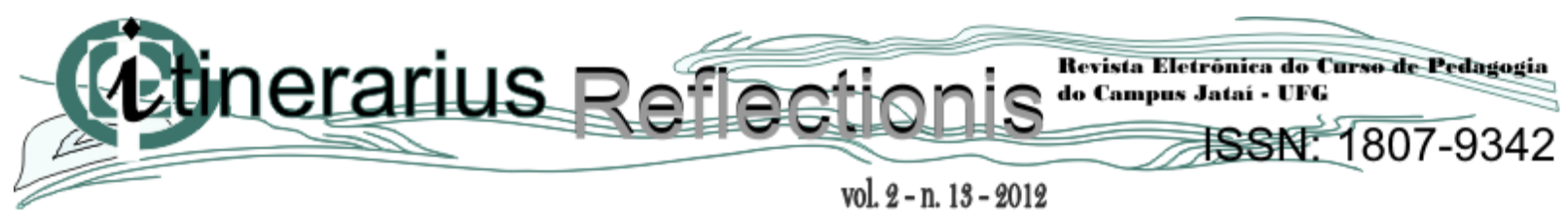

\title{
A MORAL DO RESSENTIMENTO E AS PRÁTICAS DISCRIMINATÓRIAS NA DIVERSIDADE SEXUAL
}

Renata Silva Pamplona Doutoranda em Educação pela Universidade Federal de São Carlos/UFSCar renascersempre@ hotmail.com

Nilson Fernandes Dinis Professor associado no Departamento de Educação da Universidade Federal de São Carlos/ UFSCar ndinis@ufscar.br

RESUMO: O presente trabalho objetiva questionar as práticas discriminatórias e homofóbicas infligidas à diversidade sexual. Indaga-se em que medida ações de repúdio infligidas às novas identidades sexuais e de gênero são influenciados por preceitos religiosos extremados próprios de uma moral do ressentimento. Faz-se como opção metodológica utilizar alguns conceitos elaborados por Friedrich Nietzsche, em sua obra: Genealogia da moral: uma polêmica, por entender que muitas das elaborações conceituais desse clássico contribuem para compreensões referentes ao surgimento dos valores morais cultivados na atualidade, em particular, os valores preconceituosos em relação a vivências sexuais distintas da heterossexual. Estas elaborações conceituais são confrontadas com os discursos e práticas homofóbicas vivenciados na contemporaneidade no Brasil, em especial nas instituições escolares. A conclusão a que se chega é a de que se faz urgente e necessária a construção de espaços educativos capazes de possibilitar a discussão sobre as muitas possibilidades de vivências da sexualidade, numa tentativa de enfrentamento das barbáries que são submetidas pessoas que expressam uma orientação sexual distinta da heterossexualidade.

Palavras-chave: Diversidade sexual. Homofobia. Moral do ressentimento.

\section{THE MORAL OF RESENTMENT AND DISCRIMINATORY PRACTICES ON SEXUAL DIVERSITY}

ABSTRACT: This paper aims to question homophobic and discriminatory practices inflicted
on sexual diversity. We ask to what extent repudiation actions inflicted on new sexual and
gender identities are influenced by extreme religious precepts from a moral of resentment. It
has the methodological option of using some concepts elaborated by Friedrich Nietzsche in
his work: Genealogy of Morals: a polemical tract, by understanding that many of the
conceptual elaborations of that classic book contribute to understand the emergence of moral
values cultivated in the present days, in particular, prejudiced values against different sexual 
experiences other than heterosexual ones. The conclusion that is reached is that it is very urgent and necessary to build educational spaces able to allow discussion about the many possibilities of experiences of sexuality in an attempt to cope with the atrocities that are subjected people who express a distinct sexual orientation far from heterosexuality.

Key words: Sexual diversity. Homophobia. Moral of resentment.

Propor-se a realizar um estudo sobre temáticas vinculadas à sexualidade humana é adentrar num território marcado por criações, valorações e acessos recortados pelas instâncias conceituais da linguagem e do complexo poder do discurso, que engendram determinados entendimentos sobre a sexualidade, os quais não são neutros, naturais, intrínsecos ao sujeito. Ao contrário, são produzidos, fabricados, em constantes movimentos por toda uma textura social, cultural e institucional. Segundo Michel Foucault,

O que se diz sobre o sexo não deve ser analisado como a simples tela da projeção
desses mecanismos de poder. É justamente no discurso que vêm a se articular poder
e saber. E, por essa mesma razão, deve-se conceber o discurso como uma série de
segmentos descontínuos, cuja função tática não é uniforme nem estável.
(FOUCAULT, 2010a, p. 111)

Quando a proposta se refere a pensar a temática - diversidade sexual e sua relação com o contexto educacional - são visíveis as muitas influências dos discursos que concebem e constituem compreensões a respeito da sexualidade. Crenças, valores, normas são responsáveis por um jeito de ser e compreender a si mesmo e o outro, em que o outro, quando não possui a orientação de seu desejo sexual ou afetivo voltado para o sexo oposto, geralmente é tido como o estranho, como pessoa inferior, que se distancia da hegemônica normatização heterossexual. E usualmente é acometido por ações preconceituosas e violentas em diversos espaços sociais, entre eles, os espaços escolares.

Para a historiadora Guacira Lopes Louro o sexismo e a homofobia estão densamente presentes na prática educativa e a fabricação dos sujeitos sexuais é um processo continuado e geralmente muito sutil, quase imperceptível, porém efetivo. Por sexismo entende-se a concepção androcêntrica que toma o ser masculino como uma identidade principal de referência presente tanto na linguagem, como nas práticas sociais, tal como definido pela 
pesquisadora espanhola Monserrat Moreno (1999). Quanto aos mecanismos operantes na homofobia, como ressalta o pesquisador Rogério Diniz Junqueira:

\begin{abstract}
... transcende tanto aspectos de ordem psicológica, quanto a hostilidade e a violência contra pessoas homossexuais, bissexuais, travestis, transexuais e interse-xos etc. Ela, inclusive, diz respeito a valores, mecanismos de exclusão, disposições e estruturas hierarquizantes, relações de poder, sistemas de crenças e de representação, padrões relacionais e identitários, todos voltados a naturalizar, impor, sancionar e legitimar uma única seqüência sexo-gênero-sexualidade, centrada na heterossexua-lidade e rigorosamente regulada pelas normas de gênero. (JUNQUEIRA, 2009, p.375).
\end{abstract}

O Brasil protagoniza um momento histórico de algumas conquistas referentes aos direitos de pessoas LGBTT (Lésbicas, Gays, Bissexuais, Travestis, Transexuais e Transgêneros), como: a união civil entre pessoas do mesmo sexo, aprovada em maio de 2011 pelo Superior Tribunal Federal, o lançamento pelo governo federal em 2004 do programa Brasil sem homofobia, e a presença ainda que frágil da temática sexualidade nos Parâmetros Curriculares Nacionais. No entanto, o preconceito e as práticas discriminatórias, permeadas por atos de extrema violência, continuam sendo corriqueiros. Diferentes espaços sociais e institucionais têm se constituído como palco para episódios de violência endereçados a homossexuais, lésbicas, travestis e transexuais. Não é incomum notícias sobre ridicularizações, discriminações, retaliações, maus tratos, espancamentos e até mesmo mortes, tendo essas pessoas como vítima. Tais fatos vêm ocorrendo em ambientes públicos, privados, locais de lazer, de trabalho e, fortemente, em escolas. A escola, de acordo com Louro, é um espaço em que se vivencia intensamente essa realidade. "Diferenças, distinções, desigualdades... A escola depende disso. Na verdade a escola produz isso." (LOURO, 1998, p. $57)$.

A partir desse contexto, esse artigo se propõe a questionar as práticas discriminatórias e homofóbicas endereçadas à diversidade sexual, a partir da provocação de alguns conceitos nietzscheanos. Já nas primeiras linhas no prólogo de sua Genealogia da Moral, Nietzsche afirma que o homem é um desconhecido de si. Denuncia que a humanidade não sabe estar presente ou viver de fato suas experiências, mas ao contrário é atropelada por essas, não consegue ter uma noção sobre suas ações e o que se vive, por ser ausente às suas vivências. Passa despercebida pela vida, ou antes, levada por um turbilhão, que pode ser traduzido nas instâncias sociais que controlam o agir humano e fabricam jeitos e formas desse agir. Não 
vol. 2-n. 13-2012

sem pretensões, mas afirmando uma conduta, um ideal, uma performance. Trilhando pelos caminhos da filologia, Nietzsche se aventura em uma genealogia dos conceitos que investiga, entre eles os conceitos de Verdade, Razão, Moralidade, Eticidade e a própria noção de Sujeito. Na sua transvaloração de todos os valores, a busca da verdade será a própria crítica da idéia de verdade tida como um valor absoluto. Um dos pontos principais na crítica nietzscheana é se a ascese ao mundo da Razão, da Verdade e da Moralidade é potencializadora ou não da Vida: o 'valor dos valores'. Nietzsche traça uma genealogia da moral, tendo como principal inquietude o surgimento do bem e do mau: "Sob que condições o homem inventou para si os juízos de valor 'bom' e 'mau'...” (NIETZSCHE, 1998, p. 9).

Na primeira dissertação, Nietzsche (1998) relaciona o termo Bom com nobre, aquele que se comunica com as forças instintivas da vida, que ao invés de refletir sobre si, vive a vida na sua potência, ou em outras palavras, alguém criativo, autêntico; e Ruim é por sua vez relacionado com o feio, o plebeu, o tímido, o covarde, carente de força vital. Mas, para Nietzsche a cultura judaico-cristã realizou uma inversão desses valores, enaltecendo uma moral escrava em detrimento de uma moral dos senhores. No entanto, uma ressalva deve ser feita: longe de um viés preconceituoso étnico, que associe as elaborações desse pensador ao movimento anti-semita, é preciso salientar que suas críticas se dirigiam à cultura judaicocristã como uma cultura do ressentimento, e não ao judaísmo entendido como comunidade étnica.

A inversão das noções de Bom (próprio do nobre) e Ruim (próprio do escravo) para Mal e Bom, se configurou numa profunda alteração de sentido. Enquanto a elaboração BomRuim é um movimento afirmativo, em que Bom é criado pelo nobre, a partir de dentro de si, e Ruim é apenas um pálido contraste constituindo uma representação que destoa do conceito de Bom, a elaboração Mal-Bom própria do pensamento ressentido é um movimento negativo. Mal se configura no sentimento ínfimo da inveja, raiva que o escravo nutre pelo nobre. Primeiro cria-se a noção do que é $M a l$ para só depois se criar um Bom, no qual a moral escrava se referenciara. Ela cria um Mal para só posteriormente soerguer o Bom, a partir do qual se verá numa condição superior e elevada; entretanto, reativa, ressentida.

Uma das primeiras referências sobre este tema aparece no capítulo "O que é nobre" em Para Além de Bem e Mal: 


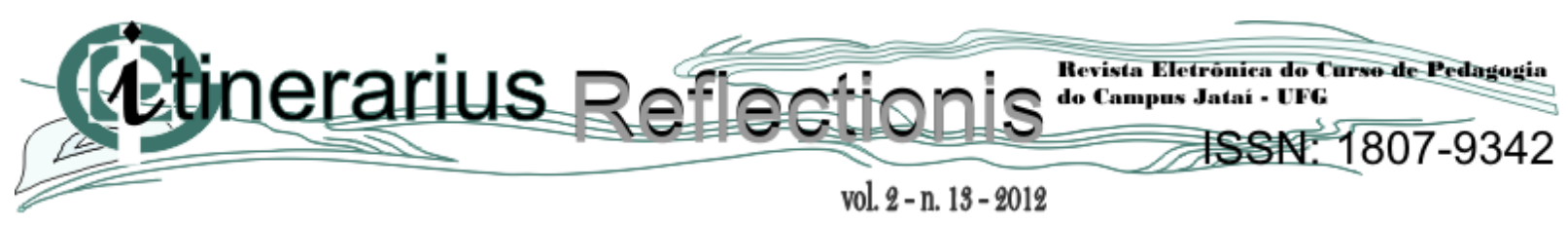

Há moral de senhores e moral de escravos [...] No primeiro caso, quando são os dominantes que determinam o conceito 'bom', são os estados de alma elevados, orgulhosos, que são sentidos como o distintivo da hierarquia. O homem nobre aparta-se dos seres em que o contrário de tais estados orgulhosos e elevados chega à expressão: ele os despreza (NIETZSCHE, 1978, p. 291).

No homem nobre está a origem do valor bom, sendo que ruim é sempre seu oposto, ou seja, o escravo: 'Note-se desde já que nessa primeira espécie de moral a oposição 'bom' e 'ruim' significa o mesmo que 'nobre' e 'desprezível': - a oposição 'bom' e 'mau' é de outra origem" (NIETZSCHE, 1978, p. 291). O homem nobre é criador, cria valores que atribui a si mesmo, como dirá Nietzsche "uma tal moral é uma glorificação de si” (NIETZSCHE, 1978, p. 292). Já com a moral escrava as palavras de Nietzsche são absolutamente implacáveis:

A moral de escravos é essencialmente moral utilitária. Aqui está o foco para o
nascimento daquela célebre oposição 'bom' e 'mau' - no mal é sentida a
periculosidade, algo de terrível, refinado e forte, que não deixa lugar para o
desprezo. Segundo a moral de escravos, portanto, o 'mau' desperta medo; segundo
a moral de senhores, é precisamente o 'bom' que desperta medo e quer despertá-lo,
enquanto o homem 'ruim' é sentido como o desprezível [...] o bom, dentro da
maneira de pensar dos escravos, tem de ser, em todo caso, o homem não-perigoso:
ele é bondoso, fácil de enganar, um pouquinho estúpido talvez, é um bonhomme.
Por toda a parte onde a moral de escravos chega à preponderância, a linguagem
mostra uma inclinação à aproximar as palavras 'bom' e 'estúpido'".( NIETZSCHE,
1978, p. 293).

O tema é retomado em sua Genealogia da Moral. Para Nietzsche, a moral escrava inverteu os valores de forma que em nossa cultura:

... os miseráveis somente são bons, apenas os pobres, impotentes, baixos são bons,
os sofredores, necessitados, feios, doentes são os únicos beatos, os únicos
abençoados, unicamente para eles há bem-aventurança - mas vocês, nobres e
poderosos, vocês serão por toda a eternidade os maus, os cruéis, os lascivos, os
insaciáveis, os ímpios, serão também eternamente os desventurados, malditos e
danados... (NIETZSCHE, 1998 p. 26).

A partir dessa inversão, Nietzsche apresenta o ressentimento como uma reação, uma rebelião da moral escrava, que em sua incapacidade de criação afirmativa, utiliza o próprio ressentimento como criador e gerador de valores. A moral nobre é legítima, ela nasce triunfante dizer sim a si mesma. Por outro lado, a moral escrava se constrói atribuindo já de início, um não ao outro, dessa forma, seria preciso antes desvalorizar, renegar o outro, distinto do eu, para que a moral escrava possa se afirmar e existir. 


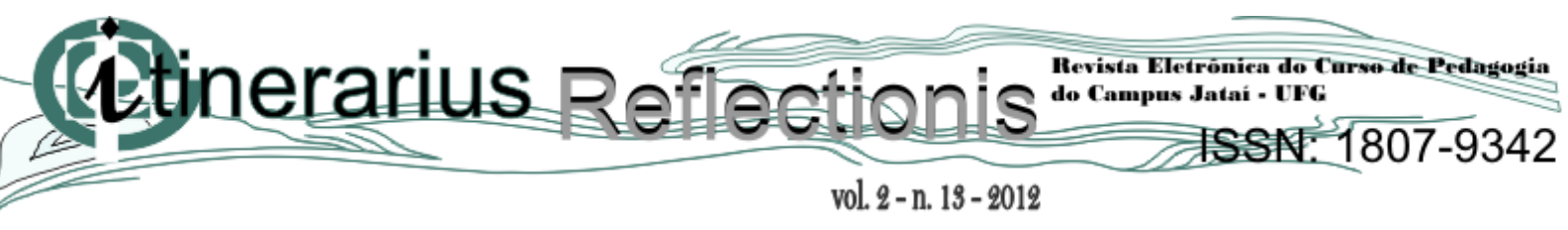

Não existiria nessa proposição possibilidades de correlação com as práticas discriminatórias contra a diversidade sexual, como a homofobia, por exemplo? Nesse caso o ressentimento consistiria em definhar o outro, por meio de discursos ofensivos, ou velados, como uma tentativa de afirmar a heterossexualidade como modelo universal de referência.

De maneira análoga, na sociedade contemporânea ocidental, as invenções conceituais da homossexualidade e heterossexualidade são utilizadas também a partir de uma inversão. Comumente os discursos são produzidos de forma a legitimar a heterossexualidade, apresentando-a como única expressão da sexualidade, normal e existente desde sempre. Mas para que este discurso se constitua e se afirme, é preciso antes negar os outros que ameaçam a constituição deste discurso por meio da violência e da exclusão social. Assim, a homossexualidade é tida como a vertente da sexualidade vinculada à idéia de perversão, patologia ou distúrbio em relação à norma heterossexual. No entanto, pouco se discorre sobre o fato da invenção conceitual da homossexualidade ter se realizado anteriormente à criação do termo heterossexualidade. A invenção e categorização do conceito homossexualidade ocorreu no final do século XIX. Segundo Foucault, "Foi por volta de 1870 que os psiquiatras começaram a constituí-la como objeto de analise médica: ponto de partida, certamente, de toda uma série de intervenções e de controles novos" (FOUCAULT, 1985, p. 233). Seguindo a trajetória do método genealógico proposto por Nietzsche e Foucault, o pesquisador Jonathan Katz (1996) ressalta como o próprio conceito de norma em torno do termo "heterossexualidade" também foi uma constituição histórica do fim do século XIX. O termo "heterossexual" teria sido criado por volta de 1892, ou seja, depois do termo "homossexual", e designava, em um primeiro momento, o amor patológico e desmedido por pessoa do sexo oposto, só posteriormente adquirindo o sentido de norma e de referência para a sexualidade.

Discursos públicos que dizem não se simpatizar ou mesmo odiar pessoas homossexuais ainda são algo não só tolerado em nossa cultura, como constituem também em uma forma bastante comum de afirmação e de constituição da heterossexualidade masculina. O pesquisador americano Donald Sabo (2002) analisa, por exemplo, como a homofobia é um dos mecanismos utilizados nas práticas esportivas na escola para ensinar jovens atletas a desenvolver e provar sua "masculinidade". Podemos lembrar também que em nossa cultura um dos primeiros xingamentos aprendidos por meninos é justamente a palavra "maricas" ou "mariquinha". A palavra lembra aos meninos acerca das duas identidades, a mulher e o 
vol. 2-n. 13-2012

homossexual, que devem ser constantemente negadas e excluídas no processo de afirmação de sua masculinidade e sua heterossexualidade.

O sentido decorrente dessa inversão conceitual dos termos homossexualidadeheterossexualidade para heterossexualidade-homossexualidade parece operar a partir de uma força reativa, que oportuniza o exercício de práticas homofóbicas. Assim, vários exemplos têm sido rotineiramente difundidos no Brasil, entre eles, encontra-se a explosão discursiva, repercutida no contexto de diversas mídias, ao material educacional kit anti-homofobia. Esse material é um dos produtos do projeto Escola Sem Homofobia, que surge dando continuidade às políticas públicas contra a homofobia, iniciadas no governo Lula (2003), especificamente com o lançamento em maio de 2004 do programa federal Brasil Sem Homofobia: Programa de Combate à Violência e à Discriminação contra GLTB e de Promoção da Cidadania Homossexual.

Frente a esse acontecimento vários discursos se propagaram a respeito do material educativo destinado a combater a homofobia em instituições escolares, entre esses, os discursos: religiosos, políticos, leigos, psicológicos, jurídicos, biológicos, educacionais. Essa estratégia discursiva culminou no veto da presidenta Dilma Rousseff, que mandou suspender no dia 25 de maio de 2011 o kit anti-homofobia, pressionada por políticos da bancada religiosa do Congresso Nacional. Outro exemplo, decorrente desse acontecimento, ocorreu no transcurso das eleições municipais de 2012 em São Paulo, quando o candidato José Serra, do Partido da Social democracia Brasileira (PSDB), tentou desmoralizar o adversário Fernando Haddad - prefeito eleito de São Paulo pelo Partido dos Trabalhadores (PT) e ex-ministro da Educação entre julho de 2005 e janeiro de 2012 - alegando ser ele o responsável pela elaboração do material kit anti-homofobia, devido ao fato do material ter sido produzido em seu ministério. Os discursos se constroem numa tentativa de forjar um certo apelo coletivo à moral do ressentimento contrária às diversidades sexuais. Para Nietzsche este é o feito e criação do homem do ressentimento que concebe seu inimigo como: “"o inimigo mau', 'o mau', e isto como conceito básico, a partir do qual também elabora, como imagem equivalente, um ‘bom' - ele mesmo!...”. (NIETZSCHE, 1998, p. 31).

A declaração de Myrian Rios, deputada estadual do Rio de Janeiro pelo PDT e exatriz, proferida em 21 de junho/2011, na tribuna da Assembléia Legislativa do Rio de Janeiro (Alerj), se configura também como exemplo. Seu discurso foi proferido contra a Proposta de 


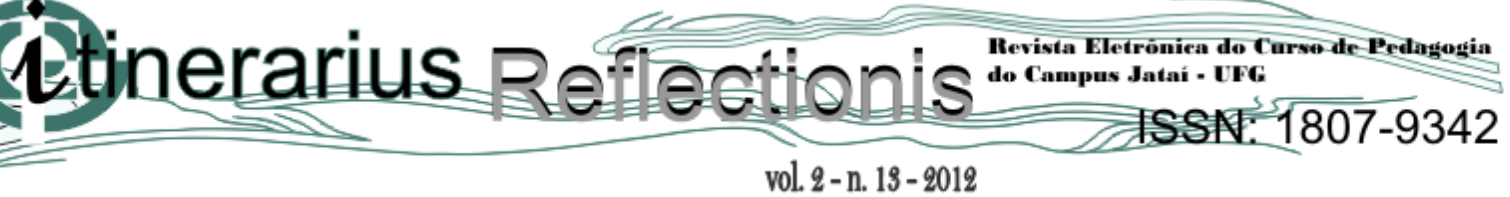

Emenda à Constituição (PEC) sobre a criminalização da homofobia. A deputada, para justificar seu posicionamento, comparou homossexuais e lésbicas a pedófilos/as. Devido à má repercussão de sua fala, Myrian Rios tentou se justificar com afirmações já conhecidas de quem tenta se posicionar como não-homofóbico, ou como quem supostamente aceita às diferenças. Ela apelou para: "não sou preconceituosa e não descrimino [...] conto na minha família com parentes e amigos homossexuais e os amo, respeito como seres humanos e filhos de Deus" (MYRIAN RIOS SE..., 2011, s. p.). Seus argumentos cristãos insurgem com a certeza de quem está convicto de sua superioridade e benevolência, por meio da negação e demonização ressentida do outro, neste caso, o sujeito homossexual. Outro político recorrente em aparecer na mídia com seus argumentos homofóbicos é o deputado federal Jair Bolsonaro, do Partido Progressista (PP-RJ). O deputado utiliza termos agressivos, ultrajantes, para explicitar e destilar seu posicionamento contrário à diversidade sexual. Ele que é um dos políticos que concentrou forças para impedir a aprovação e utilização do material educativo kit anti-homofobia.

Em relação a esse material educativo também se presenciou, por meio dos diversos discursos propagados nas mídias brasileiras, a elaboração de uma inversão do nome e sentido atribuído ao material. Esse foi apelidado de kit gay, o que remete a uma conotação contrária a que se destina, ou seja, ter por função contribuir para oportunizar reflexões sobre a diversidade sexual. Já o nome kit gay parece sugerir uma aula referente a como ser homossexual, o que contraria as motivações da elaboração do material didático de se destinarem ao enfrentamento do preconceito e das práticas homofóbicas nas escolas. A palavra kit tem origem inglesa e entre outras definições, significa o "Conjunto de elementos vendidos com um esquema de montar e que o próprio comprador pode armar: kit de aeromodelo. Jogo de elementos ou peças: kit de ferramentas" (DICIONÁRIO..., 2011, s. p.), o que sugere uma flexibilidade discursiva oferecida pela palavra kit. Da mesma forma que o utensílio, a palavra kit pode ser armada e utilizada a partir de um jogo minucioso de interesses.

O projeto Escola sem homofobia passa a ser conhecido por um dos produtos que o compõe, ou seja, o material kit anti-homofobia, e posteriormente ganha na mídia o apelido de kit gay. Visto pela definição anterior, o kit é um conjunto de material vendido para ser facilmente armado e montado. Nesse sentido, não parece indevido pensar a expressão kit gay 
como uma estratégia de venda pejorativa do projeto Escola sem homofobia e do material didático produzido, como materiais de qualidade duvidosa, ou antes, impróprios. Com o nome kit gay constrói-se um discurso maléfico, demonizando o material educativo, bem como, os sujeitos ali apresentados. Assim, arquitetam-se percepções, entendimentos e julgamentos a respeito do kit, cria-se um arsenal de discursos em torno do acontecimento Escola sem homofobia, os quais engendram novos saberes sobre a pluralidade sexual nas escolas, ao mesmo tempo em que produzem entendimentos a partir da moral do ressentimento.

Nesse sentido os discursos delegam para segundo plano o fato da escola ser um cenário corriqueiro para o exercício de diversos tipos de práticas homofóbicas, que ferem a autoestima, deixam estigmas e traumas psicológicos, marcam vidas de forma decisivas, como por exemplo, o abandono precoce da escola, às vezes em séries iniciais. Uma das principais vítimas deste processo são justamente as travestis devido à constituição de seus territórios existenciais desafiando visivelmente os territórios limítrofes da normalidade. Como ressalta William Siqueira Peres:

\begin{abstract}
A intensidade da discriminação e do desrespeito aos quais as travestis são expostas nas escolas em que desejam estudar leva, na maioria das vezes, a reações de agressividade e revolta, ocasionando o abandono dos estudos ou a expulsão da escola, o que conseqüentemente contribui para a marginalização, pois bem sabemos da importância dada aos estudos e à profissionalização em nossa sociedade (PERES, 2009, p. 245).
\end{abstract}

Peres relata diversas experiências vividas por travestis, transexuais e transgêneros, nas quais foram vítimas de violência e preconceitos homofóbicos. Os relatos são fortes e apontam a necessidade de efetivação de políticas públicas e uma Educação Sexual nas escolas que contemple em suas discussões à temática diversidade sexual. Assinalam a urgência da construção de debates e reflexões que engendrem novos espaços escolares, capazes de possibilitar novas experiências das diferenças, sem que as consideradas minorias, sejam expostas ao ridículo, à violência, ao abuso da ação e omissão de quem se julga dentro de uma superior normalidade.

Cabe também analisar, na contemporaneidade, as ações de sutil violência, que embebidas por valorações da moral do ressentimento passam despercebidas ou banalizadas nos palcos sociais, como a escola. Afinal, muitos discursos produzidos sobre a 


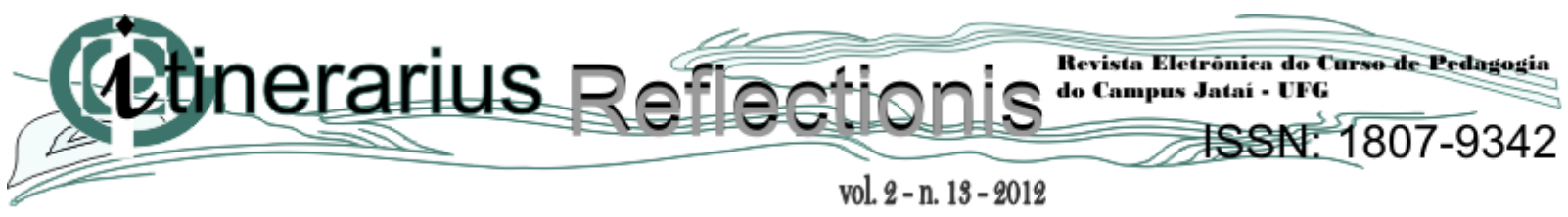

homossexualidade se estruturam por premissas que atribuem às pessoas homossexuais algum vínculo com o universo do mal, como afronta aos códigos morais e reguladores de uma sociedade patriarcal, branca e cristã. Deixando de considerar que dentro do próprio cristianismo existem inúmeras configurações de crenças e divergências, por isso, de acordo com Foucault, "Seria totalmente inexato reduzir a moral cristã - dever-se-ia, sem dúvida, dizer "as morais cristãs" (2010b, p. 38). Nietzsche considera que “... necessitamos de uma crítica dos valores morais, o próprio valor desses valores deverá ser colocado em questão" (NIETZSCHE, 1998 p. 12). Assim, seria também preciso destacar a própria ambigüidade que a palavra moral comporta, pois para Foucault:

Por "moral" entende-se um conjunto de valores e regras de ação propostas aos indivíduos e aos grupos por intermédio de aparelhos prescritivos diversos, como podem ser a família, as instituições educativas, as igrejas etc. Acontece dessas regras e valores serem bem explicitamente formulados em uma doutrina coerente e em um ensinamento explícito. Mas acontece também delas serem transmitidas de maneira difusa e, longe de formarem um conjunto sistemático, constituírem um jogo complexo de elementos que se compensam, se corrigem, se anulam em certos pontos, permitindo, assim, compromissos ou escapatórias (FOUCAULT, 2010b, p. $33)$.

Nietzsche critica o sentido da cultura do ressentimento, afirmando que a mesma não tinha intenção de explorar as potencialidades do homem, mas de sucumbi-lo sobre controles e interesses diversos.

... o sentido de toda cultura é amestrar o animal de rapina "homem", reduzi-lo a um animal manso e civilizado, doméstico, então deveríamos sem dúvida tomar aqueles instintos de reação e ressentimento, com cujo auxilio foram finalmente liquidadas e vencidas as estirpes nobres e os seus ideais, como os autênticos instrumentos da cultura... (NIETZSCHE, 1998 p. 33-34)

Nietzsche quando busca pela genealogia da moral de nossa cultura e formula o conceito de moral do ressentimento, está se dirigindo especificamente aos valores judaicocristãos que se tornaram predominantes na cultura ocidental. Neste sentido, a interferência persistente da religião nas políticas de estado no Brasil reflete a influência dessa cultura do ressentimento. Essas considerações nietzschianas permitem indagações sobre possíveis relações com a intensa e fervorosa constituição cultural religiosa no Brasil, que em nome de seus ideais ainda parece se pautar em fortes resquícios dessa moral outrora descrita por Nietzsche. 


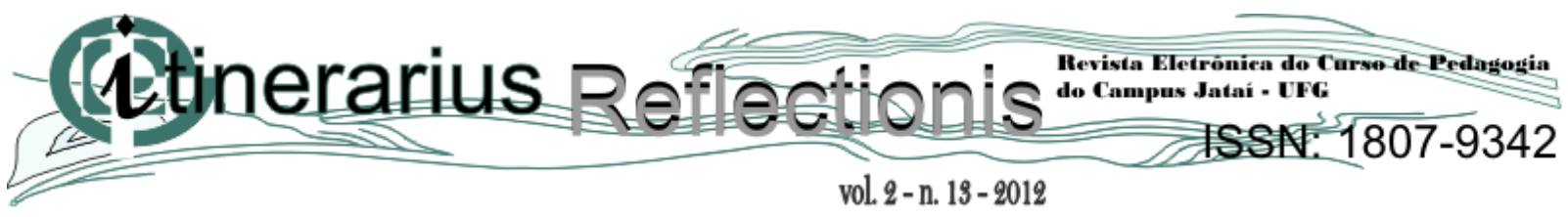

O discurso do deputado Jair Bolsonaro, da deputada Myrian Rios, assim como, vários dos discursos propagados em resposta ao material educacional kit anti-homofobia, explicitam esse recurso de se valer de crenças religiosas extremadas para se posicionarem contra a diversidade sexual. Ainda que afirmem não terem nada contra homossexuais, apenas com a conhecida defesa da moral e dos bons costumes da família, utilizam estratégias de cooptação da opinião pública. Lançam de expedientes de alusão aos ideais cristãos, e reforçam a necessidade de manutenção do status quo da família brasileira, sustentado pelo ideal burguês, heteronormativo, androcêntrico. Enaltecem a absurda suposição de que o fato de pessoas viverem distintamente sua sexualidade represente um prenúncio destrutivo da ordem estabelecida. $\mathrm{O}$ que, nesse sentido, reforça a indagação: Não existe nessa concepção uma obliteração ou cumplicidade com as ações cruéis, violentas, humilhantes, quase inimagináveis que sofrem as pessoas quem vivem uma sexualidade distinta da normatividade heterossexual?

A propagação de discursos referentes ao material educativo kit anti-homofobia se situa nessa ordem dos confrontos sobre as sexualidades e diversidades sexuais. Muitas pessoas foram até os veículos midiáticos, ou mesmo em instituições que exercem algum vínculo profissional, para poderem expressar seu entendimento sobre o então configurado escândalo, ou seja, a polêmica ocasionada por um material educativo que pretende ou pretendia discutir assuntos que confrontam a "verdade sobre o sexo" Foucault (1982). O senador Magno Malta, pertencente ao Partido da República-PR do Estado do Espírito Santo-ES, em um de seus recorrentes e inflamados discursos contra o material educacional Kit anti-homofobia, assim se manifesta:

Eu estou vindo de uma reunião na câmara, [...] Estavam presentes ateus, a bancada católica, que me autoriza a falar em nome dela, o Deputado Eros Biondini, as bancadas evangélicas e espírita, quem não confessa fé nenhuma, gente de confissão islâmica, pessoas que acreditam em família nos princípios, nos moldes de Deus. O ministro foi levado a se reunir lá na Câmara para falar desse tal kit, que está passando do limite. O que nós queremos discutir com ele - a frente da Família - é esse kit. Não há nada de orientação nesse kit. Pelo contrário. Eu estou olhando para o Brasil para afirmar o seguinte, Senador Ivo Cassol: esse kit homossexual nas escolas fará das escolas verdadeiras academias de homossexuais (SENADOR MAGNO..., 2011, s. p.).

De forma geral os discursos presentes nesse fragmento da fala do senador Magno Malta utilizam o valor da religião para produzir um pânico social ao instituir a figura do homossexual como uma ameaça ao futuro da família. Especificamente, o enunciado em que se 
vol. 2-n. $13-2012$

diz que o kit fará das escolas verdadeiras academias de homossexuais, desperta atenção, ao trazer um discurso sobre o ensinar a ser homossexual, mostrando um forte temor diante dessa possibilidade. No entanto, não há uma problematização sobre o fato de que as escolas, historicamente, também ensinam de diferentes maneiras a heterossexualidade e as formas tradicionais de ser homem e de ser mulher.

O discurso arquiteta-se enaltecendo que o objetivo dessas supostas academias de homossexuais seria a mobilização, a preparação e o ensinamento de conteúdos e habilidades específicas de como ser gay, lésbica, transexual, travesti. Nessa academia, de acordo com o enunciado, as teorias seriam aquelas que induzem as pessoas a serem homossexuais.

Esses enunciados permitem o encontro com a perspicácia e maestria com que o discurso se reverte, mostrando como a ordem discursiva é instável e produtora de inúmeras verdades, pois é interessante o exercício de tentar imaginar uma acadêmica de homossexuais numa cultura que mata o/a homossexual por um repúdio odioso. Uma inversão também ancorada em um pensamento ressentido, em um movimento negativo, pois o que os estudos sobre sexualidade, gênero, cultura, diferenças vêm demonstrando a partir de uma longa produção teórica é que na cultura ocidental contemporânea se ensina a ser homem, a ser mulher e a ser obrigatoriamente heterossexual, ao produzir valores e saberes, fabricar jeitos de ser, construir identidades masculinas e femininas, regulamentar constituições familiares. Longe está a cultura ocidental de construir uma academia, no sentido educacional, que se ensine a ser homossexual. Nas palavras de Ruth Sabat:

\footnotetext{
A reprodução da diferença se dá socialmente através da representação e tem relação direta com as relações de poder que existem na sociedade. Aprendemos, por exemplo, que masculinidade e heterossexualidade são categorias idênticas, naturais e inquestionáveis. Nesse sentido é que devemos compreender a heterossexualidade também como um significante, e como tal produzida pela linguagem em meio a relações de poder (SABAT, 2001, p. 19).
}

A completa inversão do discurso é vista pela manobra de tentar criar um temor e pânico ao fazer pressupor que no lugar da conhecida heretossexualidade ensinada desde a mais tenra infância se passará a ensinar nas escolas a ser lésbica, gay, travesti, bissexual, transexual. Uma tentativa de criar verdadeiros pânicos morais no sentido de que esses "emergem a partir do medo social com relação às mudanças, especialmente as percebidas como repentinas e, talvez, por isso mesmo, ameaçadoras (MISKOLCI, 2007, p. 103). 


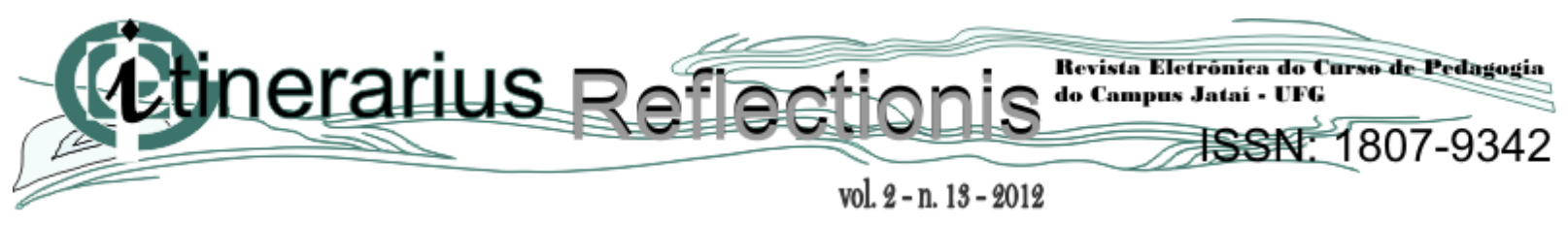

Em outro discurso contra o kit anti-homofobia proferido em 24 de novembro de 2011, o deputado Jair Bolsonaro traz uma enunciação importante sobre a não aceitação familiar em relação à homossexualidade, quando diz:

Quem tem o prazer de ter um filho gay? Agora, podem dizer: "Oh! Ele está discriminando!" Eu não tenho prazer e tenho uma tribuna para falar, e vou falar [...] Pelo amor de Deus, não cometam, não deixem que grupos homossexuais cometam essa covardia com as crianças, com as famílias, com a religião e com os bons costumes! (BRASIL, 2011, s. p.).

Sabe-se que esse é um discurso delicado quando se olha para as histórias de vida de uma maioria de pessoas homossexuais, pois muitas delas enfrentam fortes dilemas familiares e religiosos, por não receberem o apoio familiar daquela que se constituiu historicamente uma das instituições mais antigas.

Alguns aspectos desse discurso precisam ser desdobrados em suas implicações. Primeiramente, é preciso retomar o fato de que culturalmente no Brasil espera-se que a família exerça seu conjecturado papel de acolhedora e perpetuadora de alguns valores postos como os únicos verdadeiros, corretos e aceitáveis, reforçados pelo discurso religioso cristão (em sua maioria). O que contribui, ou mesmo determina extensivamente que as próprias famílias lidem mal com a homossexualidade de seus filhos ou suas filhas.

Faz-se necessário considerar que essa concepção de família nuclear, harmônica e acolhedora é mais uma verdade naturalizada que não se sustenta de forma generalizada, pois a família também é extensivamente lugar de maus-tratos, de abusos, de abandonos, de discriminações, como acontece com muitos/as homossexuais, que são execrados/as por mães, pais, irmãos, irmãs, tios, tias, primos, primas, avós, avôs. E ainda uma terceira e última consideração se refere ao fato que na contemporaneidade não cabe mais falar em famílias nucleares, pois as novas configurações familiares são cada vez mais crescentes e diferenciadas e não facilmente catalogáveis, como querem os discursos que falam em nome da família, como se essa fosse única. Os discursos reforçadores dessa concepção do modelo familiar parecem querer sustentar uma abstração a partir dessa universalização de um ideal familiar que já há algum tempo parece ser insustentável.

Foucault (1985), ao falar sobre governamentalidade em um dos cursos ministrados no College de France, em $1^{\circ}$ de fevereiro de 1978, discorre sobre a mudança da família, da 


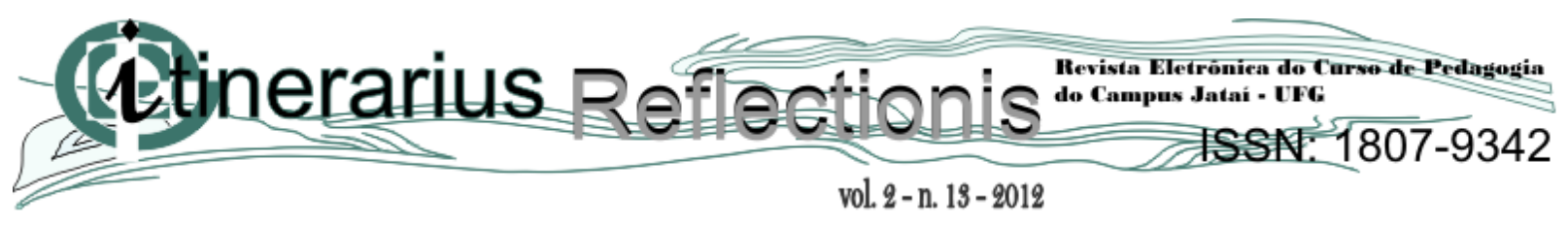

metade do século XVIII, que passa da condição de modelo para a constituição de instrumentalização, no sentido de tornar-se instrumento para o governo da população. De acordo com Foucault:

Em outras palavras, até o advento da problemática da população, a arte de governar só podia ser pensada a partir do modelo da família, a partir da economia entendida como gestão da família. A partir do momento em que, ao contrário, a população aparece como absolutamente irredutível à família, esta passa para um plano secundário em relação à população, aparece como elemento interno à população, e portanto não mais como modelo, mas como segmento. E segmento privilegiado, à medida que, quando se quiser obter alguma coisa da população - quanto aos comportamentos sexuais, à demografia, ao consumo etc. - é pela família que se deverá passar. De modelo, a família vai tornar-se instrumento, e instrumento privilegiado, para o governo da população e não modelo quimérico para o bom governo. Esse deslocamento da família do nível de modelo para o nível de instrumentalização me parece absolutamente fundamental, e é a partir da metade do século XVIII que a família aparece nesta dimensão instrumental em relação à população, como demonstram as campanhas contra a mortalidade, as campanhas relativas ao casamento, as campanhas de vacinação, etc. Portanto, aquilo que permite à população desbloquear a arte de governar é o fato dela eliminar o modelo da família (FOUCAULT, 1985, p. 288-289).

Os discursos construídos com ênfase nos valores morais familiares parecem enxergar a família com uma instituição em suspensão na sociedade, deixando assim de perceber as muitas manobras que a utilizam como ferramenta para assegurar técnicas de controle e de poder exercidos pelas mídias, pelas ciências, pelo mercado financeiro, “... pelas várias pedagogias que circulam. Filmes, músicas, revistas e livros, imagens, propagandas” (GOELLNER, 2008, p. 29).

Muitos e muitas homossexuais sofrem violentas pressões psicológicas por viverem crenças religiosas nas quais foram educados/as e que aprenderam que ser homossexual é pecado, é errado, merece castigo e condenação eterna. Segundo Borrillo:

... gays e lésbicas crescem e se desenvolvem em um ambiente que revela abertamente sua hostilidade ao homossexual. A internalização dessa violência, manifestada sob a forma de insultos, injúrias, enunciados depreciativos, condenações morais ou compaixão, conduz muitos homossexuais a lutar contra seus desejos, engendrando, não raro, graves problemas psicológicos. Culpa, ansiedade, vergonha e depressão são as principais manifestações desses problemas. O estereótipo ainda disseminado do homossexual incapaz de ter uma vida afetiva plena, sem família e crianças, e tendo que terminar seus dias em uma solidão insuportável, aliviada frequentemente pelo suicídio, assombra o espírito de diversos homossexuais (BORRILLO, 2009, p. 42). 


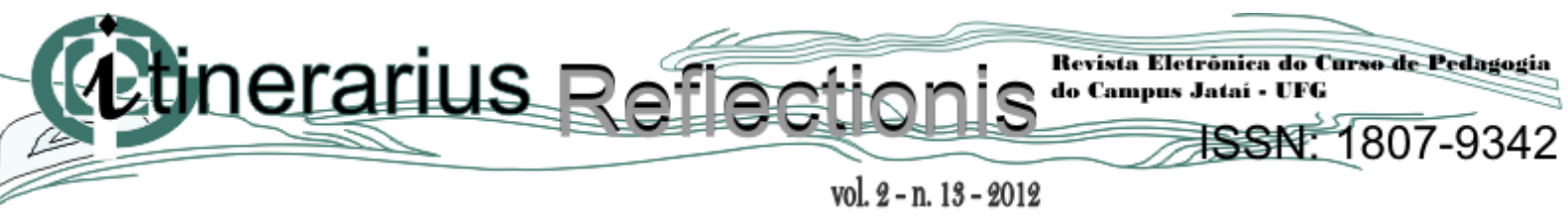

Os discursos religiosos contrários ao kit anti-homofobia afirmam, insistentemente, uma noção unívoca da religião, fé, crença, valores, fazendo crer que todas/os as/os homossexuais são uma afronta a Deus, um pecado que deve ser punido em especial quando se pretende oferecer recursos pedagógicos que levem uma discussão contra a homofobia para as instituições escolares e possibilitem o debate e conhecimento sobre as diferenças sexuais e sobre a singularidade e diferença das pessoas, de como essas sentem desejos, afetos, assim como pessoas heterossexuais. Apenas elegem um/uma parceiro/ra do mesmo sexo para se relacionarem, o que não thes retira a condição humana, os valores, a moral, a cidadania, a dignidade, pois, de acordo com Foucault, 'existem diferentes maneiras de 'se conduzir' moralmente, diferentes maneiras, para o indivíduo que age, de operar não simplesmente como agente, mas sim como sujeito moral dessa ação (FOUCAULT, 2010b, p.34).

Recentemente se vivenciou, no cenário político brasileiro, outra importante reivindicação do grupo LGBTT, protagonizada por ações ou tentativas de combate ao preconceito e esclarecimentos sobre a diversidade sexual. Refere-se à tentativa de aprovação do Projeto de Lei da Câmara (PLC) 122/2006, que propõe a criminalização da homofobia, projeto ainda não aprovado pela bancada do senado. Essa reivindicação também tem a sua não aprovação influenciada ou determinada por demandas, lideradas por grupos religiosos (católicos e evangélicos), contrários a criminalização da homofobia e a Educação Sexual nas escolas. O que traz perplexidade diante do objetivo dessa demanda ser apenas assegurar o direito e respeito das muitas formas de se viver a sexualidade, sem que pessoas sejam violentadas, agredidas, expulsas, mortas ou retalhadas nas sutilezas dos engendramentos discursivos.

Outra elaboração presente na obra nietzscheana, o conceito de má-consciência, instiga questionamentos a respeito da possibilidade de relação com as ações em defesa da boa moral de grupos contrários a diversidade sexual. Para situar esse conceito é preciso recorrer à segunda dissertação da Genealogia, momento que Nietzsche desenvolve a ideia de culpa e má-consciência, mas não de forma pontual ou linear, ao contrário, ele aponta algumas possibilidades para compreensão, em especial do conceito de má-consciência. Estabelece uma relação entre: esquecimento - memória - promessas - consciência - sentimento de culpa - máconsciência. O esquecimento seria uma forma de vitalidade, já a memória impossibilitaria o desligar das angústias, sofrimentos e conflitos. Essa memória traz para a humanidade a 
consciência, mas também a noção de culpa e dívida, sendo que essa última, a dívida, levaria o sujeito a fazer promessas na tentativa de saldá-la. O sentimento de culpa tem origem na relação pessoal entre comparador e vendedor, credor e devedor, que permitiria ao credor exigir a quitação da dívida. Na impossibilidade do pagamento, esse se conformaria em infringir algum tipo de sofrimento ao devedor. O "prazer de ultrajar", "direito à crueldade" (NIETZSCHE, 1998, p. 54). Esse devedor receberia um castigo, visando despertar em si, um sentimento de culpa, um remorso, que é uma das nomeações de Nietzsche para a máconsciência. Posteriormente o autor apresenta outras referências para a formação da máconsciência, como uma profunda doença que o homem contraiu ao inibir seus instintos mais vitais, seu instinto de liberdade em nome de se ver aceito no recinto da sociedade. Toda a força, o potencial agressivo, a hostilidade contida, é dirigida contra o próprio sujeito possuidor. Mas, Nietzsche entende que essa idéia de má-consciência enquanto instinto de liberdade reprimido é apenas uma de suas vertentes, "Somente a má consciência, somente a vontade de maltrata-se fornece a condição primeira para o valor do não-egoísmo" (NIETZSCHE, 1998, p. 76), ou seja, a idéia de um sujeito tão bom, puro, elevado, capaz de perdoar sempre o outro, dada a sua condição superior. Situando-se a partir dessa perspectiva, Nietzsche traz a ideia do advento do Deus cristão, e de toda a lógica da humanidade de se submeter ao mesmo, a qual está vinculada a ideia de culpa, que o levará a um intenso automartírio.

Já terão adivinhado o que realmente se passou com tudo isso, e sob tudo isso: essa vontade de torturar, essa crueldade reprimida do bicho-homem interiorizado, acuado dentro de si mesmo, aprisionado no "Estado" para fins de domesticação, que inventou a má consciência para se fazer mal, depois que a saída mais natural para esse querer-fazer-mal fora bloqueada - esse homem da má consciência se apoderou da suposição religiosa para levar seu automartírio a mais horrenda culminância. Uma dívida para com Deus. (NIETZSCHE, 1998, p. 81).

Em História da Sexualidade Vol. 1, Michel Foucault (2010a) ao discorrer sobre o rito da confissão promovido pelo Ocidente cristão, afirma que esse se constituiu como o primeiro artifício para se produzir a verdade sobre o sexo, e relata que paulatinamente esse sacramento da confissão emigrou para a pedagogia e para outras relações como, por exemplo, entre crianças e adultos. 


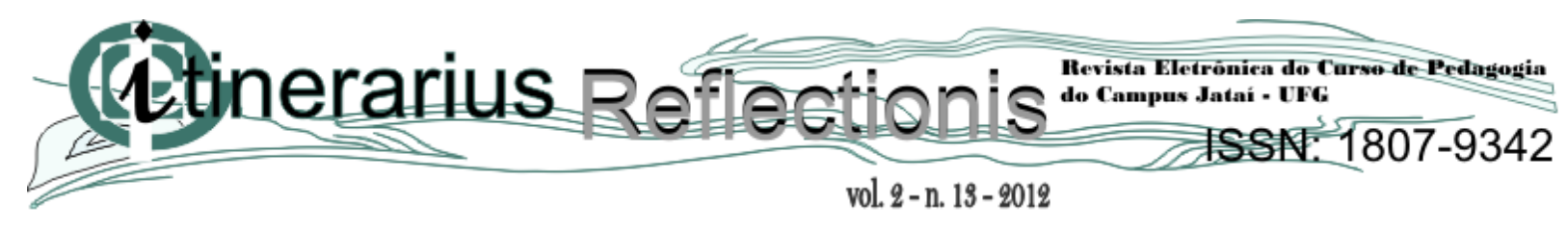

Em todo caso, há quase cento e cinqüenta anos, um complexo dispositivo foi instaurado para produzir discursos verdadeiros sobre o sexo: um dispositivo que abarca amplamente a história, pois vincula a velha injunção da confissão aos métodos da escuta clínica (FOUCAULT, 2010a, p. 77).

Essa passagem do texto de Foucault, como também grande parcela de sua produção intelectual, indica o que Nietzsche já afirmava sobre a moral do ressentimento, culpa, máconsciência, em Genealogia da Moral. E suscitam, também, questões sobre a rigidez de posicionamentos contrários à diversidade sexual, expressos em diversas instituições sociais, a exemplo das escolares.

Parece que as ações extremadas e embebidas do fervor religioso no Brasil de grupos contrários aos direitos de pessoas LGBTT, estão, de certa forma, menos envolvidas com o respeito ou por um proclamado amor pelo outro, próprio do discurso religioso, do que com um compromisso de renovar uma moral ressentida, que determina primeiro quem é o mal, ou seja, primeiro demonizando o outro, para depois afirmar reativamente o que é o bom. Em outras palavras, em alguma medida as pessoas movidas por essa moral do ressentimento e máconsciência por não poderem viver a própria sexualidade, talvez pelo desconhecimento dessa, necessitam matar o outro para se firmarem enquanto possuidoras de uma identidade boa e superior.

Essa concepção permeia os espaços escolares, o que dificulta mudanças em favor de novas formas de pensar, de ver a si mesmo e o diverso, restando à repetição de formas de se viver em que a moral do ressentimento é mais valorizada do que a criatividade estética de novos modos de existência ou da invenção de novas formas de se viver a sexualidade e a relação com as diferenças.

Para Nietzsche, “A tarefa de criar um animal capaz de fazer promessas, já percebemos, traz consigo, como condição e preparação, a tarefa mais imediata de tornar o homem até certo ponto necessário, uniforme, igual entre iguais, constante, e portanto confiável". (NIETZSCHE, 1998, p. 48). Ao contrário de uma subjetividade permeada pelas diferenças, a moral do ressentimento constrói uma subjetividade monolítica, uniforme, cristalizada e previsível.

Como dito anteriormente o objetivo primordial de uma Educação Sexual nas escolas destina-se a uma proposta de diálogo que viabilize o conhecimento, o encontro e vivência de 
vol. 2-n. $13-2012$

distintas e possíveis sexualidades, o encontro e conhecimento das diferenças, sem que se necessite de rótulos ou práticas, que enquadrem as pessoas, como: esse/a é bom/boa, ou: esse/a é mal. Essa educação permitiria o rompimento com a ideia que limita a condição humana à uniformidade, ou ainda, com a moral do ressentimento, descrita por Nietzsche.

A partir dessas proposições nietzcheanas, parece bastante razoável considerar que às práticas discriminatórias contrárias à diversidade sexual se aproximam de uma moral escrava, que por incapacidade de agir por forças potencializadoras da vida, atua reativamente contra quem ousa realizar esse movimento de afirmação da vida. Contra quem ousa subverter os valores impostos por uma cultura tradicional.

Priorizar a construção da própria vida ou o domínio de si, da produção da subjetividade a partir de experiências que enalteçam a arte da existência, da vivência dos desejos, afetos, certamente caracteriza o que Nietzsche denomina de vontade de potência. Contudo, na sociedade contemporânea, essa mesma força de vida, funciona como um dispositivo desencadeador da moral escrava do ressentimento. Rotineiramente confirmada por diversas práticas e discursos que buscam manter, estrategicamente um jogo de poder, que endossa certa legitimidade da heterossexualidade, e sua presumida aparência de naturalidade, em detrimento das diferenças sexuais.

\section{REFERÊNCIAS}

BRASIL. Câmara dos deputados DETAQ. Disponível em:

http://www.camara.gov.br/internet/sitaqweb/TextoHTML.asp?etapa=5\&nuSessao=335.1.54. O\% 20\% 20\% 20\% 20\%20\&nuQuarto $=20 \&$ nuOrador $=1 \&$ nuInsercao $=0 \&$ dtHorarioQuarto $=14: 5$ 7\&sgFaseSessao=PE $\% 20 \% 20 \% 20 \% 20 \% 20 \% 20 \% 20 \% 20 \&$ Data=24/11/2011\&txApelido=JAI R\%20BOLSONARO,\%20PP-

RJ\&txFaseSessao=Pequeno $\% 20$ Expediente $\% 20 \% 20 \% 20 \% 20 \% 20 \% 20 \% 20 \% 20 \% 20 \% 20 \% 20$ $\% 20 \&$ txTipoSessao $=$ Ordin $\%$ C3\%A1ria\%20-

\%20CD\%20\%20\%20\%20\%20\%20\%20\%20\%20\%20\%20\%20\%20\%20\%20\%20\&dtHoraQua rto $=14: 57 \&$ txEtapa $=$ Acesso em maio de 2011.

BORRILlO, Daniel. A homofobia. In: LIONÇO, Tatiana e DINIZ, Débora (Org.). Homofobia e educação - um desafio ao silêncio. Brasília: EdUnB, 2009, p. 15-46.

DICIONÁRIO ONLINE DE PORTUGUÊS. Kit. Disponível em: http://www.dicio.com.br/kit/ Acesso em Ago. 2011. 
FOUCAULT, Michel. Herculine Barbin: o diário de um hermafrodita. Rio de Janeiro: Francisco Alves, 1982.

Microfísica do poder. Rio de Janeiro: Graal, 1985.

A história da sexualidade. Vol. 1: A vontade de saber. Rio de Janeiro: Graal, 2010a.

A história da sexualidade. Vol. 2: O uso dos prazeres. Rio de Janeiro: Graal, 2010b.

GOELLNER, Silvana Vilodre. A produção cultural do corpo. In: LOURO, Guacira Lopes; FELIPE, Jane, GOELLNER, Silvana Vilodre. (Org.) Corpo, gênero, sexualidade: um debate contemporâneo na educação. Petrópolis: Vozes, 2008, p. 28-40.

JUNQUEIRA, Rogério Diniz. Educação e Homofobia: o reconhecimento da diversidade sexual para além do multiculturalismo liberal. In: Diversidade Sexual na Educação: problematizações sobre a homofobia nas escolas / Rogério Diniz Junqueira (organizador). Brasília: Ministério da Educação, Secretaria de Educação Continuada, Alfabetização e Diversidade, UNESCO, 2009.

KATZ, Jonathan. A invenção da heterossexualidade. Rio de Janeiro: Ediouro, 1996.

LOURO, Guacira Lopes. Gênero, sexualidade e educação: Uma perspectiva pósestruturalista. 2 ed. Petrópolis: Vozes, 1998.

MISKOLCI, Richard. Pânicos morais e controle social. Reflexões sobre o casamento gay. Cadernos Pagu (28), Núcleo de Estudos de Gênero Pagu/Unicamp, jan.-jun. 2007.

MYRIAN RIOS SE DESCULPA POR ASSOCIAR GAYS A PEDOFÍLOS. Disponível em: http://espacogls.com/conteudo/?tag=myriam-rios. Acesso em julho de 2011.

MORENO, Montserrat. Como se ensina a ser menina - o sexismo na escola. São Paulo: Moderna; Campinas: UNICAMP, 1999.

NIETZSCHE, Friedrich. Obras incompletas. São Paulo: Abril Cultural, 1978.

Genealogia da moral - Uma polêmica. São Paulo: Companhia das letras, 1998.

PERES, Wiliam Siqueira. Cenas de exclusões anunciadas: travestis, transexuais, transgêneros e a escola brasileira. In: JUNQUEIRA, Rogério Diniz (Org.). Diversidade Sexual na Educação: problematizações sobre a homofobia nas escolas. Brasília: Ministério da Educação, Secretaria de Educação Continuada, Alfabetização e Diversidade, UNESCO, 2009. p. 235-263.

SABAT, Ruth. Pedagogia cultural, gênero e sexualidade. Revista Estudos Feministas, v. 9, n. 1, p. 4-21, 2001. 


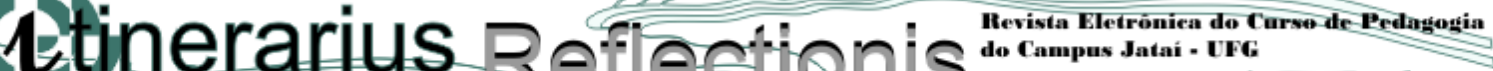 (Etherarius

SABO, Donald. $\mathrm{O}$ estudo crítico das masculinidades. In: ADELMAN, Miriam; SILVESTRIN, Celsi Brönstrup. (Orgs.). Gênero plural. Curitiba: Ed. UFPR, 2002. p. 33-46.

SENADOR MAGNO MALTA CONTRA KIT "ESCOLA SEM HOMOFOBIA" - "KIT GAY”. MP4. Disponível em: http://www.youtube.com/watch?v=B483zweaFqY Acesso em maio de 2011. 